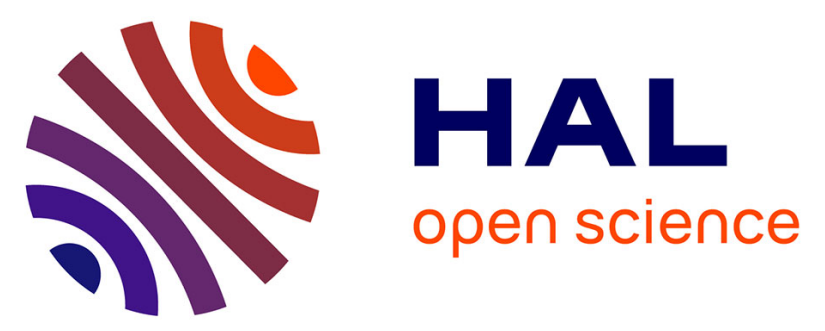

\title{
Economic and Environmental Advantages of Rubber Recycling
}

Geraldo Oliveira Neto, Henrricco Tucci, Luiz Pinto, Ivanir Costa, Roberto

Rodrigues Leite

\section{- To cite this version:}

Geraldo Oliveira Neto, Henrricco Tucci, Luiz Pinto, Ivanir Costa, Roberto Rodrigues Leite. Economic and Environmental Advantages of Rubber Recycling. IFIP International Conference on Advances in Production Management Systems (APMS), Sep 2016, Iguassu Falls, Brazil. pp.818-824, 10.1007/9783-319-51133-7_96. hal-01615797

\section{HAL Id: hal-01615797 https://hal.inria.fr/hal-01615797}

Submitted on 12 Oct 2017

HAL is a multi-disciplinary open access archive for the deposit and dissemination of scientific research documents, whether they are published or not. The documents may come from teaching and research institutions in France or abroad, or from public or private research centers.
L'archive ouverte pluridisciplinaire HAL, est destinée au dépôt et à la diffusion de documents scientifiques de niveau recherche, publiés ou non, émanant des établissements d'enseignement et de recherche français ou étrangers, des laboratoires publics ou privés. 


\title{
Economic and Environmental Advantages of Rubber Recycling
}

\author{
Geraldo Cardoso de Oliveira Neto, Henrricco Nieves Pujol Tucci, Luiz \\ Fernando Rodrigues Pinto, Ivanir Costa, and \\ Roberto Rodrigues Leite \\ Nove de Julho University, São Paulo, Brazil \\ geraldo.prod@gmail.com
}

\begin{abstract}
This research aims to evaluate the economic and environmental advantages of the adoption of Cleaner Production practices in a rubber products manufacturer. The inappropriate waste disposal of rubber was an issue to be solved, so recycle this material was the way to mitigate environmental impact. The economic gain was evaluated by calculating the return over investment and the environmental benefits through the methodology of mass intensity factor. The results showed a return over investment in 17 months, however the most expressive advantage was at the environmental perspective.
\end{abstract}

Keywords: Rubber recycling · Cleaner production · Mass Intensity Factor methodology.

\section{Introduction}

Most of the companies are oriented to generate profit, but this management style can blind them to the sustainability trends. As a consequence those companies can't keep up for a long time. Their operations have to be sustainable with initiatives such as reducing resources consumption and the reuse or recycle of materials waste, in order to get economical and environmental benefits [1]. Actions focused on the reduction of the generation of waste and the consumption of energy and raw material contribute to increase productivity, efficiency and profit. Those initiatives are aligned with the Cleaner Production $(\mathrm{CP})$ concept $[2]$.

The Brazilian government has established a Solid Waste Policy that aims to promote the adoption of the CP practices by the companies. This policy covers actions such as reduce, reuse and recycle, as well the solid waste treatment, final waste disposal, environmental education and other guidelines [3]. The CP intends to link the environmental impact reduction and the cost saving, in order to improve human health, safety and increase the process efficiency [4].

Environmental initiatives are not adopted by most of the companies due their old mindset, that believe that environmental practices are too complex, few efficient and don't return their investments [5]. 
The literature review about rubber and the CP showed three alternatives about waste: (i) mix rubber and concrete to improve durability [6]; (ii) mix rubber with a compound of glass and plastic [7]; and (iii) mix rubber and asphalt [8]. The CP practices results in economical and environmental benefits and improves the image of the company [5]. In China, half of the generated rubber waste is forwarded to automotive industry, as an alternative to recycle this material [9].

Manufacturing rubber products requires additional substances to achieve the optimal point in terms of manufacturability and composition. In order to mitigate environmental impacts, Brazilian government created laws to the companies incorporate good practices like recycling and the correct disposal of lubricants. Thus, companies have been acting to contribute on the environmental performance improvement $[10,11]$. Despite that, many companies consider that investments on those initiatives are a barrier on the CP practices implementation [12].

There are many papers related to the CP initiatives, however as a quantitative assessment, none measured the economic and environmental benefits. This indicates the gap to be explored in this research. Then, how to evaluate economic and environmental advantages with the adoption of the CP practices in the rubber recycling? Thus, this research aims to evaluate economic gain by calculating the Return Over Investment (ROI) and the environmental gain through the Mass Intensity Factor (MIF) methodology in a rubber products manufacturer.

\section{Methodology}

This case study was performed in a rubber products manufacturer. It has an exploratory purpose with both qualitative and quantitative approaches, and is a research strategy focused in comprehending the scenery to be analyzed. Evidences were gathered by interview, questionnaires and observations, in order to create the adequate conditions to understand the studied object of this research [13]. The data collected were obtained through interview with experts and through observation.

To evaluate the economic and environmental advantages with adoption of the CP practices, four steps were realised: (i)data collect; (ii)economic assessment; (iii)environmental assessment; (iv)comparison between economic and environmental gains.

In the first step, it was possible to measure the total waste and the emissions generated by the process, in order to estimate the mass balance. It was focused on the recycling of the rubber waste from the internal process and external sources through reverse logistics. In addition, it was analysed the total of saved raw material (MTE) due to the rubber recycled.

The second step is related to the economic assessment. It was calculated the Economic Gain (GE) and the period to Return On Investment (ROI), as seen in the equation 1 .

$$
R O I=\frac{\text { Investiment }}{\text { Profit in the period }}
$$


In the third step, environmental impact was measured in abiotic, biotic, water and air compartments through the Mass Intensity Factor (MIF) methodology, that considers Mass (M) and Intensity Factor (IF), as seen in the equation 2.

$$
M I F=M \times I F
$$

After that, it was calculated the Mass Intensity per Compartment (MIC), to measure theenvironmental impactreduction per compartments: abiotic (w), biotic $(\mathrm{x})$, water $(\mathrm{y})$, air $(\mathrm{z})$ and other $(\mathrm{n})$. In the equation 3is shown how calculate $\mathrm{MIC}$ for $(\mathrm{w})$, the same way for othercompartments.

$$
M I C=I F W a s t e A_{(W)}+I F W a s t e B_{(W)}+I F W a s t e C_{(W)}+\ldots
$$

Then, it is possible to calculate the Mass Intensity Total (MIT), as seen in the equation 4 .

$$
M I T=M I C_{(w)}+M I C_{(y)}+M I C_{(z)}+M I C_{(n)}
$$

In the fourth step, it was compared both economic and environmental gains to get the Economic Gain Index (IGE) and the Environmental GainIndex (IGA), as seen in the equations 5 and 6 respectively:

$$
\begin{aligned}
& I G E=\frac{M T E}{G E} \\
& I G A=\frac{M I T}{G E}
\end{aligned}
$$

Now it's possible to compare whichgain is more representative, economic or environmental [14].

Values in the table 1 refers to the Material Intensity Factors (MIF) of rubber.

Table 1. Material IntensityFactors

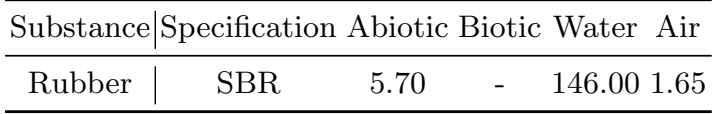

\section{Results and Discussion}

In the oldest process, all rubber waste was forwarded to the final disposal without any treatment. After process improvements, all rubber waste are now grinded and returns to the process where it is mixed with virgin raw material. It works in a closed cycle to preserve the same chemical composition and physical properties. This result is aligned with the Solid Waste Policy that aims the recycling in a closed cycle, in according to [3]. 
Further important aspect observed in this study is recycling and reuse of rubber waste that is provided as a filler charge in the rubber products manufacturing system. Thus, it can be used for production of vehicles components, in according to [9]. This finding also contributes to the literature, because cases researched addressed the use of rubber waste in other applications instead of reuse in the internal process of the company. For example, use the recycled rubber in asphalt [8], use the recycled rubber on concrete [6] and add the recycled rubber on the glass and plastic mixture [7].

Results showed that the adoption of the CP practices contributed to save costs with waste disposal and at raw material acquisition. This evidence is in according to [2] that aims to maximize the reuse of waste through recycling in the production system.

In the first step, it was collected the production data, as shown at table 2 . The average output of this company are 580 ton per month. Recycling station demands 4 operators, 2 on the first shift and 2 on the second shift. The recycling station capacity are 55 ton per month. In addition, the company acquires monthly 52 ton of virgin raw material. This finding indicates similar characteristics with other recycling and reuse processes in a production system, in according to $[5,6,7,8,9]$.

Table 2. Data collection

\begin{tabular}{l|l}
\hline Description & Amount \\
\hline Average output per month & $580,000 \mathrm{~kg}$ \\
Recycling station capacity per month & $55,000 \mathrm{~kg}$ \\
Employees & 4 (two shifts) \\
Rubber consumption per month & $52,000 \mathrm{~kg}$ \\
\hline
\end{tabular}

This company spent around USD 13,650 per month with virgin raw material acquisition. In addition, there were costs in order to dispose the generated waste, around USD 1,444 per month. So, the total costs in previous scenery were USD 15,094 per month. Recycling came up as an alternative, the operational costs to recycle the waste were around USD 7,150 per month, meaning USD 7,944 of saving per month.

Investments in equipments acquisition, infrastructure, and other expenses to build the recycling station were USD 128,750, resulting in a ROI in 17 months, as seen in table 3 . This result contributes to the literature since it demonstrates by quantitative calculations the opportunities of economic gains with the recycling and reuse of rubber in a production system. The qualitative approach is usually adopted in the researches without maths methods as cost saving, investment calculation and return on investments. This evidence is reinforced when analyzed studies of $[5,10,11,12]$.

The process generates 52 ton of rubber waste per month. The inappropriate disposal results in $296,400 \mathrm{~kg}$ in the abiotic compartment, $7,592,000 \mathrm{~kg}$ in the 
Table 3. Economic assessment

\begin{tabular}{|l|lr|}
\hline & Description & Costs (USD) \\
\hline \multirow{3}{*}{ Monthly cost } & Monthly raw material acquisition (52 ton) & $13,650.00$ \\
& Monthly waste disposal & $1,444.00$ \\
\cline { 2 - 3 } Investment & Virgin raw material + waste disposal & $15,094.00$ \\
& Monthly rubber recycling (52 ton) & $7,150.00$ \\
\cline { 2 - 3 } & Monthly economic gain with recycling & $7,944.00$ \\
\hline & Cylinder 1500 x 500 mm & $45,000.00$ \\
& Rubber mill 1100 x 800 & $55,000.00$ \\
& Vibration equipment for 30 mash & $21,250.00$ \\
& Transport and other expenses & $7,500.00$ \\
\cline { 2 - 3 } & Total investment & $128,750.00$ \\
& Return On Investment (ROI) & 17 months \\
\hline
\end{tabular}

water compartment and $85,800 \mathrm{~kg}$ in the air compartment. Then, it was identified environmental benefits with the CP practices implementation, as seen at table 4. Thus, the total reduction of environmental impact was $7,974,200 \mathrm{~kg}$. This result contributes to advance the current literature due to demonstrate the reduction of environmental impact in the abiotic, biotic, water and air compartments through the adoption of environmental assessment methodology, in according to [14]. The qualitative approach is usually employed in researches to show the potential environmental gain or demonstrated by the percentage of mass balance, as verified in studies of $[5,10,11,12]$.

Table 4. Environmental assessment

\begin{tabular}{l|cccc}
\hline Rubber & Abiotic Biotic & Water & Air \\
\hline IF & 5.70 & - & 146.00 & 1.65 \\
Mass & 52 & - & 52 & 52 \\
MIC & 296,4 & - & $7,592,000$ & 85,8 \\
\hline MIT & \multicolumn{4}{|c}{$7,974,200 \mathrm{~kg}$} \\
\hline
\end{tabular}

The Economic Gain Index (IGE) and the Environmental Gain Index (IGA) were compared, as seen at table 5 . It was demonstrated by calculating IGE that corresponds to $6.54 \mathrm{~kg} / \mathrm{USD}$ of goods saved.

When considered the Mass Intensity Total (MIT) by each USD, there is a benefit of $1,003.80 \mathrm{~kg}$ of goods that are not modified nor taken from the ecosystems. So, this case study has demonstrated that it's possible to get economic and environmental gains through adoption of the CP practices. Finally, the comparision of the economic and environmental gains also contributes to the science. 
Table 5. Comparison between economic and environmental gains

\begin{tabular}{l|cc}
\hline & IGE & IGA \\
\hline Mass & $52,000 \mathrm{~kg}$ & $7,974,200 \mathrm{~kg}$ \\
GE & USD $7,944.00$ & USD $7,944.00$ \\
\hline & $6.54 \mathrm{~kg} / \mathrm{USD}$ & $1,003.80 \mathrm{~kg} / \mathrm{USD}$ \\
\hline
\end{tabular}

\section{Conclusions}

The present research demonstrated that the adoption of the $\mathrm{CP}$ practices in a rubber products manufacturer, resulted in economic and environmental gains, that was this research objective. The environmental gain was very expressive, 153 higher than the economic gain, justifying the adoption of the rubber recycling. In addition, it was verified an economic gain with the return over investments in 17 months. This results contribute to increase the knowledge about this subject, as well to encourage other companies to the preservation of the natural resources.

The environmental impact due the inappropriate waste disposal was known by the company, however the costs saving and comply with the ISO 14000 requirements were the main reasons to implement the rubber recycling.

This research limitation consists in the application of a unique case, so it's not possible to generalize the results. It's suggested to perform new researches to allow comparisons.

\section{References}

1. Jabbour, C.J.C.: Non-linear Pathways of Corporate Environmental Management: A Survey of ISO 14001-Certified Companies in Brazil. Journal of Cleaner Production 18(12), 1222-1225 (2010)

2. Almeida, C., GIANNETTI, B.F.: Ecologia Industrial: Conceitos, Ferramentas e Aplicações. São Paulo: Edgard Blucher (2006)

3. Joinhas, L.A., S.A.S.J.S.R.: Logística Reversa, Sustentabilidade e Educação. São Paulo: Todas as Musas (2013)

4. Limpas, C.C.N.D.T.: http://www.pha.poli.usp.br/LeArq.aspx?id_arq=7985

5. Gombault, M., Versteege, S.: Cleaner Production in SMEs Through a Partnership with (Local) Authorities: Successes from the Netherlands. Journal of Cleaner Production 7(4), 249-261 (1999)

6. Richardson, A.E., Coventry, K.A., Ward, G.: Freeze/thaw Protection of Concrete with Optimum Rubber Crumb Content. Journal of Cleaner Production 23(1), 96$103(2012)$

7. Osmani, M.: Innovation in Cleaner Production Through Waste Recycling in Composites. Management of Environmental Quality: An International Journal 24(1), 6-15 (2012)

8. Oliveira, J.R., Silva, H.M., Abreu, L.P., Fernandes, S.R.: Use of a Warm Mix Asphalt Additive to Reduce the Production Temperatures and to Improve the Performance of Asphalt Rubber Mixtures. Journal of Cleaner Production 41, 15$22(2013)$ 
9. Liu, Y., Liu, Y., Chen, J.: The Impact of the Chinese Automotive Industry: Scenarios Based on the National Environmental Goals. Journal of Cleaner Production 96, 102-109 (2015)

10. Ghosh, A., Rajeev, R., Bhattacharya, A., Bhowmick, A., De, S.: Recycling of Silicone Rubber Waste: Effect of Ground Silicone Rubber Vulcanizate Powder on the Properties of Silicone Rubber. Polymer Engineering and Science 43(2), 279-296 (2003)

11. Nabil, H., Ismail, H.: Fatigue Life, Thermal Analysis and Morphology of Recycled Poly (ethylene terephthalate)/Commercial Fillers Hybrid Filled Natural Rubber Composites. Progress in Rubber, Plastics and Recycling Technology 30(2), 115 (2014)

12. Van Berkel, R., Willems, E., Lafleur, M.: Development of an Industrial Ecology Toolbox for the Introduction of Industrial Ecology in Enterprises-I. Journal of Cleaner Production 5(1), 11-25 (1997)

13. Yin, R.K.: Case Study Research: Design and Methods. Sage publications (2015)

14. Neto, G.C.O., Souza, S.M., Baptista, E.A.: Cleaner Production Associated with Financial and Environmental Benefits: A Case Study on Automotive Industry. In: Advanced Materials Research. vol. 845, pp. 873-877. Trans Tech Publ (2014) 